\title{
ESTIMATE OF THE CROP COEFFICIENT FOR Eucalyptus CULTIVATED UNDER IRRIGATION DURING INITIAL GROWTH
}

Maria Emília Borges Alves ${ }^{1}$ Everardo Chartuni Mantovani², Gilberto Chohaku Sediyama³, Júlio César Lima Neves ${ }^{4}$

(received: February 9, 2011; accepted: December 21, 2012)

\begin{abstract}
The expansion in areas planted with eucalyptus crops has raised concern about the effects these may have on water resources and existing correlations between water use and crop productivity, which calls for better understanding of water requirements by plant species. The objective of this study was to determine the water requirements of an irrigated eucalyptus crop, having the estimated dual crop coefficient $\left(\right.$ dual $K_{c}$ ) as a reference. Mean values found for estimated crop coefficients were $0.57,0.13$ and 0.70 for $K_{e}, K_{c b}$ and $K_{c}$ respectively during initial growth stage, and $0.01,0.81$ and 0.82 for $K_{e}, K_{c b}$ and $K_{c}$ respectively during the mid-season stage. The methodology used in this study is not intended to replace field measurements for development of $K_{c}$ curves. However, it provides a consistent method to evaluate values measured while providing means for estimating variations in values of $K_{c}$ according to change in the soil fraction covered by vegetation.
\end{abstract}

Key words: Water requirements of eucalyptus, eucalyptus $k c$, eucalyptus irrigation, dual $k c$.

\section{ESTIMATIVA DO COEFICIENTE DE CULTURA DO EUCALIPTO CULTIVADO SOB IRRIGAÇÃO DURANTE O CRESCIMENTO INICIAL}

RESUMO: A expansão das áreas cultivadas com eucalipto tem gerado preocupação quanto a seus efeitos sobre os recursos hídricos e as relações entre o uso da água e a produtividade da cultura, tornando necessário o entendimento de suas necessidades hídricas. $A$ proposta deste trabalho foi determinar as necessidades hidricas da cultura do eucalipto irrigado, tendo como referência a estimativa do coeficiente dual de cultura $\left(K_{c}\right.$ dual ). Os valores médios para os coeficientes de cultura estimados foram de 0,57; 0,13 e 0,70 para $K_{e}, K_{c b}$ e $K_{c^{\prime}}$ respectivamente, na fase inicial de crescimento e de 0,01; 0,81 e 0,82 para $K_{e^{\prime}}, K_{c b}$ e $K_{c^{\prime}}$, respectivamente, na fase média de crescimento da cultura. A metodologia empregada, no presente trabalho, não substitui as medidas em campo para o desenvolvimento das curvas de $K_{c}$. Entretanto, fornece uma forma consistente de avaliar os valores medidos, bem como fornecer meios para estimar as alterações nos valores de $K_{c}$ com a mudança da fração de solo coberta por vegetação.

Palavras-chave: Necessidades hídricas eucalipto, kc eucalipto, irrigação eucalipto, $k c$ dual.

\section{INTRODUCTION}

Brazil is one of the world's leading producers of timber and byproducts of nonnative forests, with a data record of 6.3 million hectares of nonnative forests in 2009 and showing an average growth of $7.1 \%$ a year between 2004 and 2009 (ASSOCIAÇÃO BRASILEIRA DE PRODUTORES DE FLORESTAS PLANTADAS - ABRAF, 2010). Among forest species, those of the genus eucalyptus have been the most popularly used, occupying nearly 20 million ha worldwide (IGLESIAS; WISTERMANN, 2008).

This massive expansion in eucalyptus crops has raised concern about the effects it has on local water resources (ALMEIDA et al., 2010), which calls for, according to Hubbard et al. (2010), researchers to seek more information on how water use by such crops will vary as a function of crop productivity and management intensity.

The amount of water needed by a crop to compensate loss by evapotranspiration $\left(E T_{c}\right)$ is defined as the water requirements and may be estimated based on meteorological elements and by directly incorporating parameters of crop resistance, albedo and air resistance, according to Penman-Monteith model. This model was later parameterized by FAO (Food and Agriculture Organization) for a hypothetical reference crop, giving rise to the Penman-Monteith-FAO method, which is used for estimating reference evapotranspiration $\left(E T_{o}\right)$.

\footnotetext{
${ }^{1}$ Agricultural Engineer, DSc in Agricultural Meteorology - Instituto CNA/ICNA - SGAN 601, Módulo K - 70.830-903 - Brasília, DF, Brasil mebalves@hotmail.com

${ }^{2}$ Agricultural Engineer, Professor DSc in Agronomy (Irrigation Management) - Universidade Federal de Viçosa/UFV - Departamento de Engenharia Agrícola - Av. P.H. Rolfs, s/n - Campus Universitário - 36.570-000 - Viçosa, MG, Brasil - everardo@ufv.br

${ }^{3}$ Agronomic Engineer, Professor PhD in Water and Soil Conservation - Universidade Federal de Viçosa/UFV - Departamento de Engenharia Agrícola Av. P.H. Rolfs, s/n - Campus Universitário - 36.570-000 - Viçosa, MG, Brasil - g.sediyama@ufv.br

${ }^{4}$ Agronomic Engineer, Professor DSc in Plant Production - Universidade Federal de Viçosa/UFV - Departamento de Solos - Av. P.H. Rolfs, s/n Campus Universitário - 36.570-000 - Viçosa, MG, Brasil - julio_n2003@yahoo.com.br
}

Cerne, Lavras, v. 19, n. 2, p. 247-253, abr./jun. 2013 
The $E T / E T_{o}$ ratio can be experimentally determined for different crops and is known as the crop coefficient $\left(K_{c}\right)$ (ALLEN et al., 1998; DOORENBOS; PRUITT, 1977). $K_{c}$ thus integrates crop characteristics (variable according to phenological stage) and local climate into the estimation of $E T_{c}$ (DOORENBOS; PRUITT, 1977).

$K_{c}$ values currently available in literature are often intended for estimation of evapotranspiration $\left(E T_{c}\right)$ of irrigated crops, demanding considerable effort to obtain values for forest species such as eucalyptus. And unlike annual species, whose water consumption will vary according to the development stage, in forest species the water requirements can be said to be constant from crop establishment, when species reach maximal leaf area.

Allen et al. (1998) introduced two methods to estimate $K_{c}$, the first combines effects of crop transpiration and soil evaporation into a singular $K_{c}$ while the second determines these effects separately using two coefficients: basal crop coefficient $\left(K_{c b}\right)$ to describe plant transpiration and soil evaporation coefficient $\left(K_{e}\right)$ to describe evaporation occurring on the surface soil layer, so that $K_{c}$ can be represented by equation 1 , termed dual $K_{c}$.

$$
K_{c}=K_{c b}+K_{e}
$$

where $K_{c}=$ dimensionless crop coefficient; $K_{c b}=$ dimensionless basal crop coefficient, tabulated as per phenological stage; $K_{e}$ $=$ dimensionless soil evaporation coefficient.

Calculating dual $K_{c}$ enables greater accuracy, since $K_{e}$ varies considerably according to meteorological elements and surface layer moisture, particularly in rainy seasons and using total area irrigation.

Studies exploring dual $K_{c}$ under the specific edaphic conditions of Brazil are scarce and yet critical to enable assessing the accuracy of using a singular $K_{c}$ and perhaps to contribute toward adjustments. With that in mind, the objective of this study was to determine the water requirements of an irrigated eucalyptus crop in Rio Doce region, MG, having the estimate of dual crop coefficient $\left(\right.$ dual $\left.K_{c}\right)$ as a reference.

\section{MATERIAL AND METHODS}

Estimation of the dual crop coefficient (dual $K_{c}$ ) of the eucalyptus crop was based on data collected from the experimental site in Santana do Paraíso, Minas Gerais state, a municipality situated at coordinates $19^{\circ} 18^{\prime} 23^{\prime \prime} \mathrm{S}$ and $42^{\circ} 22^{\prime} 46^{\prime \prime} \mathrm{W}$, at an altitude of $220 \mathrm{~m}$, in Rio Doce basin, in areas owned by Celulose Nipo Brasileira
(CENIBRA S.A.). The local average annual precipitation is $1,163 \mathrm{~mm}$, average annual temperature is $25.2^{\circ} \mathrm{C}$, average maximum temperature is $31.5{ }^{\circ} \mathrm{C}$, average minimum temperature is $19.1{ }^{\circ} \mathrm{C}$, and average relative humidity is $65.2 \%$, all measurements obtained during the experimental period between October 2001 and June 2008.

\subsection{Study site}

The experimental crop was established on October 17, 2001 and consisted of plants from four clonal genetic materials of eucalyptus: three clones of Eucalyptus grandis and a clonal hybrid of E. grandis x E. urophylla, termed 'urograndis', planted with in-between spacing of $3 \times 3.33$ $\mathrm{m}$, in a soil rated as clayish.

The area was irrigated by means of a drip irrigation system. The estimation of water requirement was based on $E T_{o}$, as determined by the standard PenmanMonteith-FAO method (ALLEN et al., 1998), setting 5 $\mathrm{mm} \mathrm{d}^{-1}$ as maximum requirement in the period of greater evapotranspiration.

Meteorological data were obtained from a meteorological station close to the experimental site. Determinations included water content at field capacity (CC) and water content at permanent wilting point (PM), in the $0-0.20 \mathrm{~m}$ depth layer.

\subsection{Estimate of the dual crop coefficient (dual $K_{d}$ )}

The methodology proposed by Allen et al. (1998) was used for estimating dual $K_{c}$, whose calculation routine is provided below.

\subsubsection{Estimate of the basal crop coefficient $\left(K_{c b}\right)$}

The first step in estimating $K_{c b}$ was to define the duration of crop growth stages (initial stage, development stage, mid-season stage and late-season stage) and to select values of $K_{c b(T a b)}$ for such stages, as suggested by Allen et al. (1998). These authors have tabulated values of $K_{c b}$ for various crops. However, such values were determined for subhumid climates $\left(U R_{\text {min }} \approx 45 \%\right)$ with moderate wind speeds $\left(u_{2} \approx 2 \mathrm{~m}\right.$ $\left.\mathrm{s}^{-1}\right)$. For other climate conditions, as is the case with the experimental site in this study, adjusting $K_{c b(T a b)}$ values was required by using equation 2 .

$$
\begin{aligned}
& K_{c b}=K_{c b(T a b)}+\left[0,04 \times\left(u_{2}-2\right)-0,004 \times\left(U R_{\min }-45\right)\right] \\
& \times\left(\frac{h}{3}\right)^{0,3}
\end{aligned}
$$

Cerne, Lavras, v. 19, n. 2, p. 247-253, abr./jun. 2013 
where $K_{c b}=$ dimensionless basal crop coefficient, tabulated as per phenological stage; $K_{c b(T a b)}=$ dimensionless tabulated $K_{c b}$ value, as suggested by Allen et al. (1998); $u_{2}=$ mean daily wind speed during the phenological stage at $2 \mathrm{~m}$ height $\left(\mathrm{m} \cdot \mathrm{s}^{-1}\right)$ for $1 \mathrm{~m} \mathrm{~s}^{-1} \leq \mathrm{u}_{2} \leq 6 \mathrm{~m} \mathrm{~s}^{-1} ; U R_{\min }=$ mean daily minimum relative humidity during the phenological stage (\%) for $20 \% \leq \mathrm{UR}_{\min } \leq 80 \%$; and $h=$ mean plant height during the phenological stage $(\mathrm{m})$ for $0.1 \leq \mathrm{h} \leq 10 \mathrm{~m}$.

Because $K_{c b(T a b)}$ values are not available for eucalyptus crops, some considerations were given so that $K_{c b}$ could be estimated under the conditions of this study. That required setting the threshold between end of development stage and start of mid-season stage when the leaf area index (IAF) reached 3, after one year of crop establishment, according to data presented by Lourenço (2009). The start of late-season stage was defined based on the maximum mean annual yield increase (IMA) found. According to Assmann (1970) and Demolinari (2006), the start of senescence for eucalyptus crops is when IMA reaches its maximum value, which in this case was 67 months after crop establishment.

According to Allen et al. (1998), values of $K_{c b(T a b)}$ suggested for mid-season and late-season stages should be used only for the maximum height values of the relevant crop they have been established for, which, in the case of softwoods (the reference crop in this study) is $10 \mathrm{~m}$. Based on this limitation and despite the fact that, where forest species are concerned, water is a constant requirement from crop establishment, this estimate was done for the initial stage, for the development stage and for the first six months of the mid-season stage, coinciding with age one and a half years (545 days) after crop establishment.

Daily $u_{2}$ and $U R_{\min }$ data were used as obtained from the local meteorological station during the study period.

2.2.2 Estimate of the soil evaporation coefficient $\left(K_{e}\right)$

$K_{e}$ was defined by the following equation:

$K_{e}=K_{r} \times\left(K_{c \max }-K_{c b}\right) \leq f_{e w} \times K_{c \max }$

(lowest between the two equation terms)

where $K_{e}=$ dimensionless soil evaporation coefficient; $K_{c \max }=$ dimensionless maximum value of $K_{c}$ following rain or irrigation; $K_{r}=$ dimensionless evaporation reduction coefficient, dependent on the cumulative depth of water depleted (evaporated) and set daily; and $f_{e w}=$ fraction of the soil that is both exposed to vertical exchanges of energy and that is wetted, expressed as $\%$.
For the calculation of daily $K_{e}$, three steps were required: calculating $K_{\text {cmax }}$, calculating $K_{r}$ and calculating $f_{e w}$, with equations 4,5 and 11 respectively.

$$
K_{c \max }=\text { máx }\left(\left\{1,2+\left[0,04\left(u_{2}-2\right)-0,004\left(U R_{\min }-\right.\right.\right.\right.
$$

45) $\left.\left.] \times\left(\frac{h}{3}\right)^{0,3}\right\},\left\{K_{c b}+0,05\right\}\right)$

The values of $u_{2}, U R_{\min }$ and $h$ used in this equation were the same as used for estimating $K_{c b}$ (equation 2).

$K_{r}$ was calculated daily and defined in two stages. In stage 1, it is the vertical exchanges of energy between surface soil layer and atmosphere that limit evaporation, with the surface well wetted (after rain or irrigation); $K_{r}$ $=1$. In stage $2, K_{r}$ was calculated according to equation 5 .

$K_{r}=\frac{T E W-D_{e, i-1}}{T E W-R E W}$

where $T E W$ (total evaporable water $)=$ maximum depth of water that can be evaporated from the soil surface, expressed as mm (equation 6), REW (readily evaporable water $)=$ total depth of water that can be evaporated during stage $1\left(K_{r}=1\right)$, ranging from $8 \mathrm{~mm}$ to $12 \mathrm{~mm}$ (tabulated) depending on soil texture (sandy and clayish respectively) expressed as $\mathrm{mm}$; and $D_{e, i-1}$ (depth of evaporation) = cumulative depth of evaporation (depletion) from the soil surface layer at the end of the previous day (i-1), expressed as $\mathrm{mm}$ (equation 7).

$T E W=\frac{(C C-0,5 P M)}{10} \times Z_{e}$

where $C C=$ water content at field capacity, as \%; $P M=$ water content at permanent wilting point, as $\%$; = depth of the surface soil layer that is subject to drying by way of evaporation, as $\mathrm{cm}$ (10 to $15 \mathrm{~cm}$ ).

$$
D_{e, i}=D_{e, i-1}-\left(P_{i}-R O_{i}\right)-\frac{I_{i}}{f_{w}}+\frac{E_{i}}{f_{e w}}+T_{e w, i}+D P_{e, i}
$$

where $D_{e, i}=$ cumulative depletion depth from the evaporating layer at the end of day $i$, as $\mathrm{mm} ; P_{i}=$ precipitation on day $i$, as $\mathrm{mm} ; R O_{i}=$ precipitation runoff from the soil surface on day $i$, as $\mathrm{mm} ; I_{i}=$ irrigation depth on day $i$, as $\mathrm{mm} ; E_{i}=$ evaporation on day $i$ (equation 8), as $\mathrm{mm} ; T_{e w, i}=$ depth of transpiration from the exposed and

Cerne, Lavras, v. 19, n. 2, p. 247-253, abr./jun. 2013 
wetted fraction of the soil surface layer on day $i$, as $\mathrm{mm}$; $D P_{e, i}=$ deep percolation loss on day $i$ (equation 9), as mm.

$E_{i}=K_{e} \times E T_{o}$

$D P_{e, i}=\left(P_{i}-R O_{i}\right)+\frac{I_{i}}{f_{w}}-D_{e, i-1}$

To initiate the daily water balance, the user can assume that all evaporable water has been depleted from the surface soil layer at the beginning of calculations so that $D_{e, i-1}=T E W$. The term $T_{e w, i}$ was assumed to be 0 (zero) based on observations by Allen et al. (1998) that the amount of transpiration extracted from the evaporating soil layer is generally small and can be ignored. $P_{i}$ values were obtained from the local meteorological station and $I_{i}$ values correspond to water depths applied to the crop throughout the study period.

The exposed and wetted fraction of the soil surface layer $\left(f_{e w}\right)$ was calculated by equation 10 :

$$
f_{e w}=\min \left(1-f_{c}, f_{w}\right)
$$

where $f_{c}=$ the average fraction of soil surface effectively covered by vegetation; $1-f_{c}=$ the approximate fraction of soil surface that is effectively exposed and not shaded by the crop, ranging from 0.01 to 1 ; and $f_{w}=$ fraction of the ground surface wetted by irrigation or precipitation, ranging from 0.01 to 1 .

Finally, $K_{c}$ was determined according to equation 1 .

\section{RESULTS AND DISCUSSION}

Estimated values of $K_{c b}, K_{e}$ and $K_{c}$ are illustrated in Figure 1. It was noted that $K_{c}$ reached values above 1.00 in the initial crop stage, to a maximum of 1.18 . These values are considered high for this crop stage, as here $K_{c}$ values are expected to be in the range of 0.70 due to small leaf area and consequently low transpiration rates.

Values of $K_{e}$ were noted to oscillate considerably during that stage. These oscillations were due to variations in the soil water content as a result of precipitation and irrigation events. This pattern was reported by Allen and Pereira (2009), who provided the generalized curve of $K_{c}$ and pointed out that abrupt variations in $K_{e}$ are governed by the frequency with which the soil is wetted. LópezUrrea et al. (2009), working with onion in central Spain,

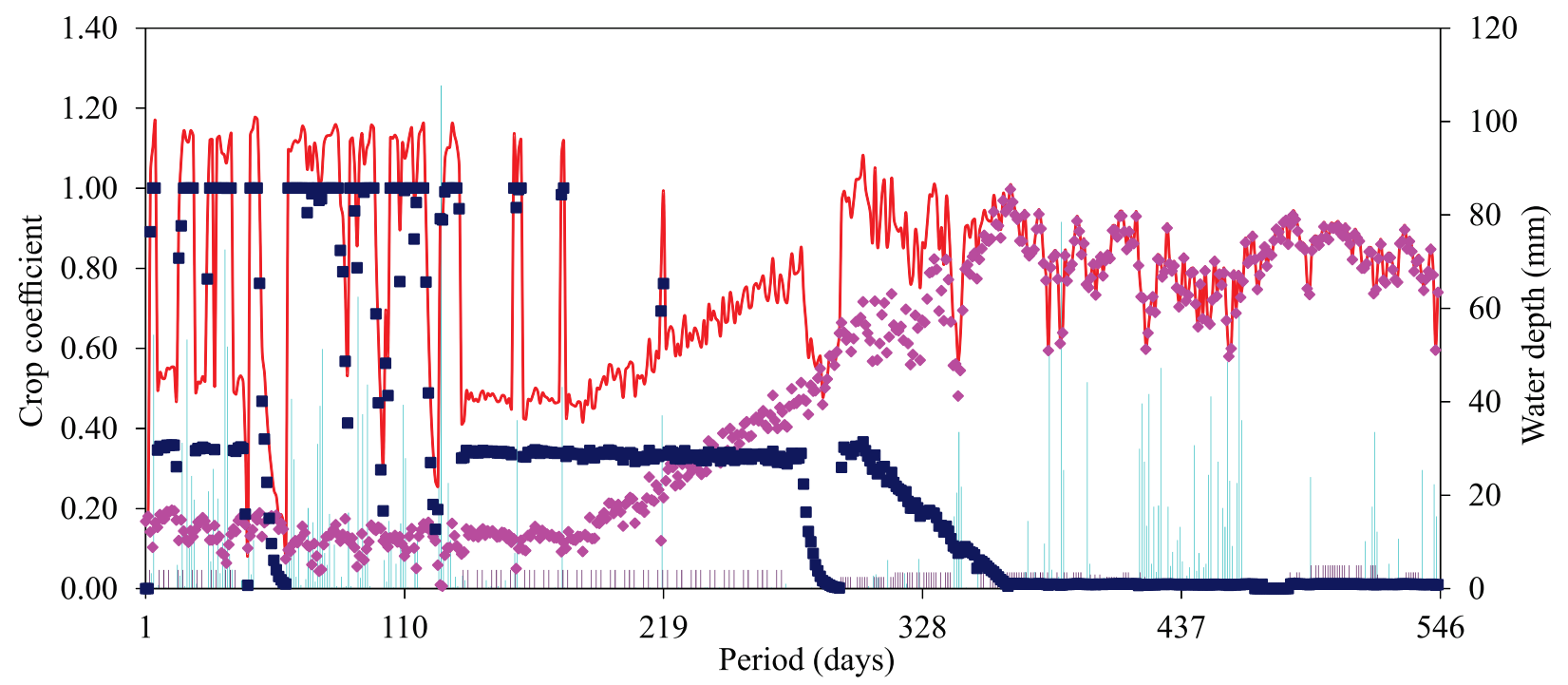

Precipitation Irrigation $-\mathrm{Kcb} \cdot \mathrm{Ke}-\mathrm{Kc}$

Figure 1 - Values of crop coefficient $\left(K_{c b}, K_{e}\right.$ and $\left.K_{c}\right)$ estimated for the eucalyptus crop cultivated under irrigation, according to the dual $K_{c}$ methodology proposed by Allen et al. (1998), for the water regime observed in the period 17.Oct.2001 to 14.Apr.2003, in Rio Doce region - MG.

Figura 1 - Valores de coeficiente de cultura $\left(K_{c b}, K_{e}\right.$ e $\left.K_{c}\right)$ estimados para a cultura do encalipto cultivada sob irrigação, de acordo com a metodologia do Kc dual proposta por Allen et al. (1998), para o regime hídrico observado no período de 17/10/2001 a 14/04/2003, na região do Rio Doce-MG.

Cerne, Lavras, v. 19, n. 2, p. 247-253, abr./jun. 2013 
found that $K_{e}$ values varied in the crop establishment stage as a function of irrigations being applied and, therefore, followed the same trend as has been shown here.

Calculation of $K_{e}$ is strongly influenced by values of $f_{e w}$, which mark abrupt variations in $K_{e}$ from one day to the next. This factor is dependent on values of $f_{w}$ which, according to the methodology, ranged from 0.01 to 1 and, for the work in question, values found ranged from 0.30 (percentage of area wetted by irrigation) to 1 (percentage of area wetted by precipitation, that is, total area), there being no intermediate values, leading to such abrupt variations in $K_{e}$ values.

According to the above observations, adjustments were made to the methodology used, consisting of setting the maximum value of $K_{e}$ at 0.80 , reducing values of $K_{c}$ to less than 1.00, and working with the artifice of moving averages to reduce peaks found in the curve of $K_{e}$, the results of which are illustrated in Figure 2.

$K_{e}$ was noted to reach maximum values in the initial stage of development, when the soil area that is exposed is greater and, according to the season when the crop was established, that stage coincided with occurrence of heaviest rainfall (October to April), allowing the soil to be continually wetted and thus providing higher values of evaporation as a result of water availability in the soil, when $K_{r}=1$. This phenomenon is described by Hillel (1971), who argues that after the soil is wetted, constantly and in subsequent periods, two very distinguished stages are noted in the process of soil dewatering or soil drying. The first stage is more constant, in which the rate of evaporation is determined by soil surface conditions and by external factors such as rain or radiation. In the second stage, a reduction occurs in such rate and evaporation proceeds as determined by the soil profile in order to transport moisture to the evaporation zone.

The pattern of $K_{c b}$ values was as expected, as the resulting curve followed the trend proposed by Allen et al. (1998), slightly varying from one day to the next as a result of being based on daily $u_{2}$ and $U R_{\min }$ data. Minimum values were reached in the initial stage of development while maximum values were reached in the mid-season stage, when there is total coverage of the soil and maximum values of IAF. According to Mielke et al. (1999), in this period, transpiration can account for over $90 \%$ of ETc, which is confirmed by Almeida et al. (2007), who argue that transpiration is the main component of water use by forests.

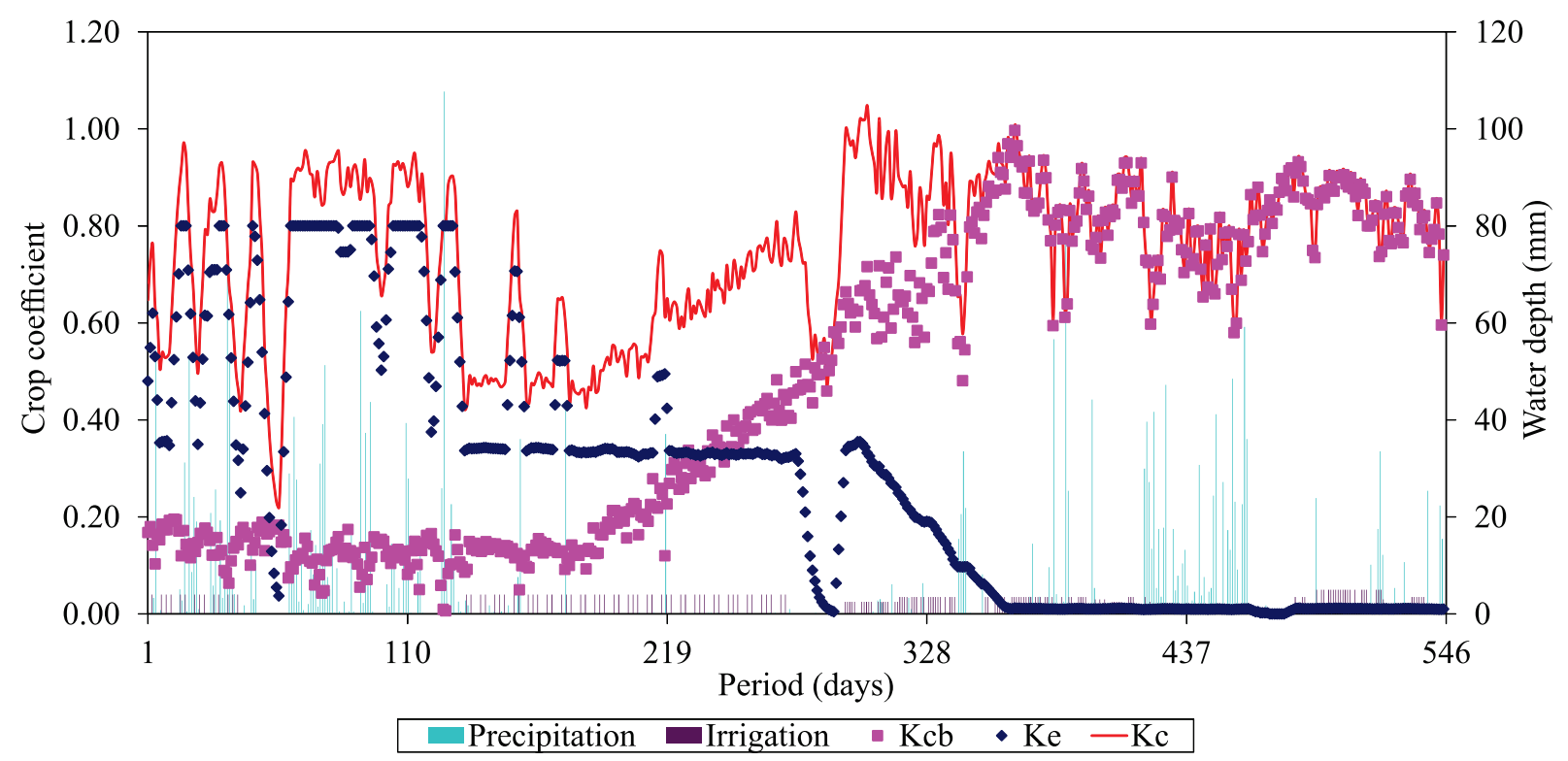

Figure 2 - Adjusted crop coefficients $\left(K_{c b}, K_{e}\right.$ and $\left.K_{c}\right)$ estimated for the eucalyptus crop cultivated under irrigation, according to the dual $K_{c}$ methodology proposed by Allen et al. (1998), for the water regime observed in the period 17.Oct.2001 to 14.Apr.2003, in Rio Doce region - MG.

Figura 2 - Valores de coeficiente de cultura ajustados $\left(K_{c b}, K_{e}\right.$ e $\left.K_{c}\right)$ estimados para a cultura do eucalipto cultivada sob irrigação, de acordo com a metodologia do Kc dual proposta por Allen et al. (1998), para o regime hídrico observado no periodo de 17/10/2001 a 14/04/2003, na região do Rio Doce - MG.

Cerne, Lavras, v. 19, n. 2, p. 247-253, abr./jun. 2013 
In this study, estimated mean values of crop coefficient are 0.57, 0.13 and 0.70 for $K_{e}, K_{c b}$ and $K_{c}$ respectively during the initial stage of development, and $0.01,0.81$ and 0.82 for $K_{e}, K_{c b}$, and $K_{c}$ respectively during the mid-season stage.

Given the characteristics of eucalyptus, it is certain that the mean values of dual crop coefficient found here are within the expected range for this crop in the initial stage. In the mid-season stage, however, it can be said that the value of $K_{c}$, for the reasons specified previously, is slightly higher than found here. This fact is likely justified by $K_{e}$ values possibly being higher than estimated in that stage, since, although the soil may be fully covered, intermittent wetting of the soil can cause more evaporation even if in smaller proportions, and that would lead to an increase in $K_{c}$ values in that crop stage.

That methodology was used by Medeiros et al. (2009), whose values of crop coefficient for corn were found to be very close to values available in literature, while López-Urrea et al. (2009) found that the values of crop coefficient estimated by this methodology were underestimated if compared with values measured by lysimeters. These authors ascribe underestimation to the fact that the adjusted $K_{c b}$ values are very low in the initial growth stage, while $K_{e}^{c b}$ values are low in the mid-season stage, which makes the aggregate $\left(K_{c}\right)$ in these two periods reach lower values than expected.

Er-Raki et al. (2010) compared the evapotranspiration of an olive crop estimated by the dual $K_{c}$ method with field-measured evapotranspiration by using sap flow sensors, and found consistent estimates of plant transpiration and soil evaporation. These authors argue that, despite the simplicity of the water balance model used, the dual $K_{c}$ methodology can correctly simulate crop evapotranspiration, providing encouraging results for partition of $E T$ into soil evaporation and plant transpiration.

The methodology used for estimating dual $K_{c}$ is a function of the fraction of effectively covered soil and of crop height. Therefore, this generalized method does not replace field measurements of $K_{c}$ for developing curves of crop coefficient. However, according to Allen and Pereira (2009), it provides a consistent method to evaluate measured values, while providing means for estimating variations in $K_{c}$ values with change in the soil fraction covered by vegetation. This is important in estimations of $K_{c}$ for tree species, as it may vary considerably depending on spacing, pruning and age of trees.

Cerne, Lavras, v. 19, n. 2, p. 247-253, abr./jun. 2013

\section{ACKNOWLEDGEMENTS}

The authors wish to thank the Research Aid Foundation of Minas Gerais State (FAPEMIG) for granting a doctoral scholarship to the first author, and Celulose Nipo Brasileira (CENIBRA S.A.) for allowing access to the experimental data that enabled this study.

\section{REFERENCES}

ALLEN, R. G.; PEREIRA, L. S. Estimating crop coefficients from fraction of ground cover and height. Disponível em: <http://www.springerlink.com.w10041.dotlib.com.br/ content/2g253616n23w1562/fulltext.pdf>. Acesso em: 22 out. 2009.

ALLEN, R. G.; PEREIRA, L. S.; RAES, D.; SMITH, M. Guidelines for computing crop water requeriments. Rome: FAO, 1998. 308 p. (FAO Irrigation and Drainage, 56).

ALMEIDA, A. C.; SIGGINS, A.; BATISTA, T. R.; FONSECA, S.; LOOS, R. Mapping the effect of spatial and temporal variation in climate and soils on Eucalyptus plantation production with 3-PG, a process-based growth model. Forest Ecology and Management, Amsterdam, v. 259, p. 1730-1740, 2010 .

ALMEIDA, A. C.; SOARES, J. V.; LANDSBERG, J. J.; REZENDE, G. D. Growth and water balance of Eucalyptus grandis hybrid plantations in Brazil during a rotation for pulp production. Forest Ecology and Management, Amsterdam, v. 251, p. 10-21, 2007.

ASSMANN, E. The principles of forest yield study. Oxford: Pergamon, 1970. $506 \mathrm{p}$.

ASSOCIAÇÃO BRASILEIRA DE PRODUTORES DE FLORESTAS PLANTADAS. Anuário estatístico da ABRAF 2010: ano base 2009. Brasília, 2010. 140 p.

DEMOLINARI, R. de A. Crescimento de povoamentos de eucalipto não-desbastados. 2006. 72 p. Dissertação (Mestrado em Ciência Florestal) - Universidade Federal de Viçosa, Viçosa, 2006.

DOORENBOS, J.; PRUITT, J. O. Guidelines for predicting crop water requeriments. Rome: FAO, 1977. 179 p. (FAO Irrigation and Drainage, 24). 
ER-RAKI, S.; CHEHBOUNIB, A.; BOULETB, G.; WILLIAMS, D. G. Using the dual approach of FAO-56 for partitioning ET into soil and plant components for olive orchards in a semi-arid region. Agricultural Water Management, Amsterdam, v. 97, p. 1769-1778, 2010.

HILLEL, D. Soil and water, physical principles and processes. New York: Academic, 1971. 228 p.

HUBBARD, R. M.; STAPE, J. L.; RYAN, M. G.;ALMEIDA, A. C.; ROJAS, J. Effects of irrigation on water use and water use efficiency in two fast growing Eucalyptus plantations. Forest Ecology and Management, Amsterdam, v. 259, p. 1714-1721, 2010.

IGLESIAS, G. T.; WISTERMANN, D. Eucalyptus universalis global cultivated Eucalyptus forest map. Eucalyptologics: information on Eucalyptus cultivation worlwide. Lugo: GIT Forestry Consulting, 2008. Disponível em: $<$ http://www.gitforestry.com>. Acesso em: 8 set. 2010 .

LÓPEZ-URREA, R.; SANTA OLALLA, F. M.; MONTORO, A.; LÓPEZ-FUSTER, P. Single and dual crop coefficients and water requirements for onion (Allium cepa L.) under semiarid conditions. Agricultural Water Management, Amsterdam, v. 96, p. 1031-1036, 2009.

LOURENÇO, H. M. Crescimento e eficiência do uso de água e nutrientes em eucalipto fertirrigado. 2009. 145 p. Dissertação (Mestrado em Solos e Nutrição de Plantas) - Universidade Federal de Viçosa, Viçosa, 2009.

MEDEIROS, R. P.; LYRA, G. B.; SOUZA, J. L.; LYRA, G. B.; FERREIRA JÚNIOR, R. A.; BRITO, J. E. D. Coeficiente de cultura dual para o milho em quatro épocas de plantio no município de Arapiraca, Alagoas. In: CONGRESSO BRASILEIRO DE AGROMETEOROLOGIA, 16., 2009, Porto Alegre. Anais... Porto Alegre: SBAGRO, 2009. 1 CD-ROM.

MIELKE, M. S.; OLIVA, M. A.; BARROS, N. F.; PENCHEL, R. M.; MARTINEZ, C. A.; ALMEIDA, A. C. Stomatal control of transpiration in the canopy of a clonal Eucalyptus grandis plantation. Trees, Berlin, v. 13, p. 152-160, 1999.

Cerne, Lavras, v. 19, n. 2, p. 247-253, abr./jun. 2013 
